\title{
INDONESIAN CONDITION: WHAT FACTORS ARE INFLUENCE MICRO ENTERPRISES TO FACE THE INDUSTRIAL ERA 4.0?
}

\author{
Pariasa I.I. ${ }^{*}$, Medea R.U., Faizal F. \\ Department of Agricultural Social Economics, Faculty of Agriculture, \\ University of Brawijaya, Malang, Indonesia \\ ^E-mail: pariasa@ub.ac.id
}

\begin{abstract}
The local businesses is facing global competition in the industrial era 4.0 is a major challenge for the economic development of the Indonesian, many policies and programs of the central and regional governments that encourage increased competitiveness of business actors, especially micro enterprises. This study identified the factors are influence the performance of Malang micro enterprises to face the industrial era 4.0. The results showed that the knowledge of Micro enterprises in Malang about Industrial Era 4.0 was still lacking. There are two variables that have a large category, namely the variable Knowledge (X2) and Business Size (X3) against Readiness $(Y)$ with the resulting value of 0.005 and $>0.001$. This means that the variable Knowledge (X2) and Business Size (X3) has a large influence on the variable Readiness $(Y)$.
\end{abstract}

\section{KEY WORDS}

Businesses, competitiveness, enterprises, public service.

The potential possessed by micro enterprises will certainly vary according to available resources. Considering that micro enterprises is a form of local-based creative economy. The involvement of all global political stakeholders, ranging from the public sector, private sector, academia, to civil society so that industry 4.0 challenges can be managed into opportunities. Irianto (2017) states that the industry's readiness in facing the industrial era 4.0 is a major challenge that must be corrected and prepared in facing the needs and characteristics of the global market. In addition, a trusted workforce, the ease of socio-cultural arrangements as well as diversification and job creation are also industry challenges and opportunities 4.0.

According to the Central Statistics Agency of East Java Province (2018), in 2017 it was recorded that Micro enterprises in Malang Raya as a whole reached $8.58 \%$ of the total micro enterprises in East Java, equivalent to 392,526 micro enterprises. However, only a small portion of these micro enterprises understand the competition strategy and industry era standardization 4.0 .

\section{RESULTS AND DISCUSSION}

According to Ghozali and Hengky (2017), the loading factor requirements of $>0.7$ for confirmed studies and $\mathbf{0 . 6}$ are still acceptable for explanatory studies. While the requirements for AVE value must meet> 0.5 . The following is the loading factor value and AVE which can be seen in Table 1.

The results show that indicator X2.2 on the latent variable of knowledge does not meet the requirement of convergent validity with a value of 0.565 which is less than 0.6 . Therefore, indicators that do not meet the requirements must be eliminated to improve the construct. Whereas the AVE score obtained by each indicator has fulfilled the requirements of $>0.5$.

According to Ghozali and Hengky (2017), to measure discriminant validity the AVE square root value must be greater than the correlation between latent constructs. The following is the square root value of Average Variance Extracted (AVE) which can be seen in Table 2.

According to Abdillah and Hartono (2015), the reliability test in PLS can use two methods, that are Cronbach's alpha and composite reliability. However, composite reliability 
is considered better in estimating the internal consistency of a construct (Abdillah and Hartono, 2005). Rule of thumb composite reliability value is $>0.7$ although 0.6 is still acceptable. Following are the results of the internal consistency reliability tests of each construct that can be seen in Table 3.

Table 1 - Loading Factor and AVE Value

\begin{tabular}{|c|c|c|c|c|}
\hline Code & Variable & AVE & Loading Factor & P-Value \\
\hline $\mathrm{X} 1$ & Experience & 0.651 & & \\
\hline $\mathrm{X} 1.1$ & Age & & 0.807 & $<0.001$ \\
\hline $\mathrm{X} 1.2$ & Business life & & 0.807 & $<0.001$ \\
\hline $\mathrm{X} 2$ & Knowledge & 0.524 & & \\
\hline $\mathrm{X} 2.1$ & Education level & & 0.721 & $<0.001$ \\
\hline $\mathrm{X} 2.2$ & Training activities & & 0.565 & $<0.001$ \\
\hline $\mathrm{X} 2.3$ & Computer and internet used & & 0.857 & $<0.001$ \\
\hline X3 & Business size & 0.779 & & \\
\hline X3.1 & Total labor & & 0.882 & $<0.001$ \\
\hline $\mathrm{X} 3.2$ & Return (Rp/month) & & 0.882 & $<0.001$ \\
\hline $\mathrm{X} 4$ & Inovation & 0.609 & & \\
\hline X4.1 & Frecuency of product changed & & 0.808 & $<0.001$ \\
\hline$X 4.2$ & Inovation idea & & 0.838 & $<0.001$ \\
\hline $\mathrm{X} 4.3$ & Search the new product information & & 0.688 & $<0.001$ \\
\hline $\mathrm{X} 5$ & Network & 0.547 & & \\
\hline $\mathrm{X} 5.1$ & Network with consummer & & 0.783 & $<0.001$ \\
\hline$\times 5.2$ & Network with supplier & & 0.756 & $<0.001$ \\
\hline $\mathrm{X} 5.3$ & Network with big business & & 0.748 & $<0.001$ \\
\hline $\mathrm{X} 5.4$ & Network with assosiation & & 0.632 & $<0.001$ \\
\hline $\mathrm{X} 5.5$ & Network with goverment & & 0.769 & $<0.001$ \\
\hline $\mathrm{Y}$ & Readiness & 0.802 & & \\
\hline $\mathrm{Y} 1.1$ & Ready to competed the industrial era 4.0 & & 0.895 & $<0.001$ \\
\hline Y1.2 & Internalization intention & & 0.895 & $<0.001$ \\
\hline
\end{tabular}

Source: Primary data processed (2019).

Table 2 - AVE Square Root Value

\begin{tabular}{lllllll}
\hline & $\mathrm{X} 1$ & $\mathrm{X} 2$ & $\mathrm{X} 3$ & $\mathrm{X} 4$ & $\mathrm{X} 5$ & $\mathrm{Y}$ \\
\hline X1 & $(0.807)$ & 0.119 & 0.056 & 0.019 & 0.160 & -0.258 \\
X2 & 0.119 & $(0.724)$ & 0.442 & 0.424 & 0.321 & 0.509 \\
X3 & 0.056 & 0.442 & $(0.882)$ & 0.293 & 0.518 & 0.630 \\
X4 & 0.019 & 0.424 & 0.293 & $(0.781)$ & 0.420 & 0.298 \\
X5 & 0.160 & 0.321 & 0.518 & 0.420 & $(0.740)$ & 0.288 \\
Y & -0.258 & 0.509 & 0.630 & 0.298 & 0.288 & $(0.895)$ \\
\hline
\end{tabular}

Source: Primary data processed (2019).

Table 3 - Internal Consistency Reliability

\begin{tabular}{lc}
\hline & Composite Reliability \\
\hline X1 & 0.789 \\
X2 & 0.763 \\
X3 & 0.876 \\
X4 & 0.823 \\
X5 & 0.857 \\
Y & 0.890 \\
\hline
\end{tabular}

Source: Primary data processed (2019).

The composite reliability value on all variables has met the requirements of $>0.6$. So it can be concluded that each variable has a high internal consistency and good reliability so that it can be used in this study. Evaluasi Model Struktural (Inner Model).

Evaluation of structural models in PLS according to Abdillah and Hartono (2015) can be evaluated through R-Square values. The R-Square value is used to measure the degree of variation in the changes of the independent variable to the dependent variable. The higher 
the R-Square value means the better the proposed research model. The following is a structural evaluation in this study which can be seen in Table 4.

Table 4 - Structural Evaluation

\begin{tabular}{lcccccc}
\hline & $\mathrm{X} 1$ & $\mathrm{X} 2$ & $\mathrm{X} 3$ & $\mathrm{X} 4$ & $\mathrm{X} 5$ & $\mathrm{Y}$ \\
\hline $\begin{array}{l}\text { R-Square } \\
\text { Adj. } R \text {-Square }\end{array}$ & & & & & 0.832 \\
$\begin{array}{l}\text { Q-Square } \\
\text { Full Collin VIF }\end{array}$ & & & & & & 0.797 \\
\end{tabular}

Source: Primary data processed (2019).

Based on the analysis it is known that R-Square and Adj. R-Square scores 0.832 and 0.797 . This value indicates that the R-Square value is included in the strong category of more than 0.70 so it can be said that the predictor of the model is sufficient to explain the variance well. R-Square value of 0.832 means that the experience, knowledge, business magnitude, innovation, and network variables have an influence of $83 \%$ on the readiness variable. While the Q-Square value of 0.673 indicates that $\mathrm{Q}$-Square is included in the strong category of more than 0.35 so that it can be said that the model has predictive relevance and shows strong predictive validity. Full Collin VIF value $<3.3$ explains that in this study there was no collinearity problem.

The evaluation of the Goodness of Fit model according to Ghozali and Hengky (2017) in the warpPLS analysis uses 10 measurements namely Average Path Coefficient (APC), Average R-Squared (ARS), Average Adjusted R-Squared (AARS), Average Block VIF (AVIF), Average Full Collinearity VIF (AFVIF), Tenenhaus GoF (GoF), Sympson's Paradox Ratio (SPR), R-Squared Contribution Ratio (RSCR), Statistical Suppression Ratio (SSR), and Nonlinear Bivariate Causality Direction Ratio (NLBCDR).

Table 5 - Goodness of Fit Model

\begin{tabular}{llll}
\hline Index & Values & Standard Value & Result \\
\hline APC & $0.316, P=0.013$ & $p<\alpha(\alpha=0.05 / 5 \%)$ & Accept \\
ARS & $0.832, P<0.001$ & $p<\alpha(\alpha=0.05 / 5 \%)$ & Accept \\
AARS & $0.797, P<0.001$ & $p<\alpha(\alpha=0.05 / 5 \%)$ & Accept \\
AVIF & 1.441 & $\leq 3.3$ & Accept \\
AFVIF & 1.734 & $\leq 3.3$ & Accept \\
GoF & 0.737 & Small $\geq 0.1$, medium $\geq 0.25$, large $\geq 0.36$ & Large \\
SPR & 1 & Accept if $\geq 0.7$, ideal $=1$ & Accept \\
RSCR & 1 & Accept if $\geq 0.9$, ideal $=1$ & Accept \\
SSR & 1 & $\geq 0.7$ & Accept \\
NLBCDR & 1 & $\geq 0.7$ & Accept \\
\hline
\end{tabular}

Source: Primary data processed (2019).

Hypothesis testing is done to determine the effect of a direct relationship on one construct to another construct by looking at the value of the path coefficient and P-value. If a $\mathrm{P}$-Value $<0.05$ (Alpha 5\%) is obtained, the value is significant, so the hypothesis is accepted. However, if the P-value> 0.05 (Alpha 5\%), then the value is not significant, so the hypothesis is rejected.

Table 6 - Hypothesis Testing

\begin{tabular}{llll}
\hline Hypothesis & Path Coefficient & $P$. Value & Result \\
\hline H1:Experience influences the micro enterprisesreadiness & -0.210 & 0.106 & Reject \\
\hline H2:Knowledge influences the micro enterprises readiness & 0.409 & 0.005 & Accept \\
\hline H3:Business size affects themicro enterprises readiness & 0.616 & $<0.001$ & Accept \\
\hline H4:Innovation affects the micro enterprises readiness & 0.084 & 0.317 & Reject \\
\hline H5:Network influences themicro enterprises readiness & 0.259 & 0.059 & Reject \\
\hline
\end{tabular}

Source: Primary data processed (2019). 
The results found that are two accepted hypotheses and there are three hypotheses rejected because it has a p-value $>0.005$. Knowledge and business sizevariables are influenced the readiness of the micro enterprises. Knowledge consists of the level of education as well as the use of computers and the internet that can affect the readiness of Micro enterprises in realizing the industrial era 4.0. The higher the level of education, the easier it is to absorb the use of technology, while the size of the business consists of the number of workers and turnover that can affect the readiness of Micro enterprises in facing the industrial era 4.0. Even though in its application it uses computers and sophisticated technology, it still needs human resources who are able to maximize the performance of Micro enterprises.

The experience, innovation, and network variables did not affect the readiness of Micro enterprises in facing the industrial era 4.0. Innovation is expected to be able to encourage the readiness of Micro enterprises supported by network and experience. Experience has a negative relationship with the readiness of Micro enterprises which means that the high level of age and duration of trying to reduce micro enterprises readiness. As the owner's age increases and the length of time he strives, innovation decreases (Andrianto, 2016). The network owned by Micro enterprises also does not significantly encourage the readiness of Micro enterprises to face the industrial era 4.0. This is due in the field conditions on average Micro enterprises do not have a good relationship with several associations or government institutions that can support micro enterprises performance in industry 4.0.

The results showed that the knowledge of Micro enterprises in Malang about Industrial Era 4.0 was still lacking.Knowledge and business size variables are significant influenced the readiness of the micro enterprisesto face industrial era 4.0 with the p-value 0.005 and $<0.001$. But the experience, inovation and network variables are not significant influenced the readiness of the micro enterprises to deal with industralization because $p$-value show 0.106 , 0.317 and 0.059 .

\section{CONCLUSION}

The implementation of delay selling activity in rice farming business was conducted by Rice Milling Unit (RMU) managed by GapoktanMutiaraTani. This unit provides mill and storage for farmers who want to delay their selling. Rice storage can be done partially so that farmers feel safe and flexible when they want to sell or take their grains. Furthermore, it is supported by warehouse facility with the capacity reaching 10 tons.

Agribusiness development in rice farming business with delay selling activity gives more benefits compared to non-delay selling activity. Regarding total cost, delay selling actors have higher cost than those non-delays selling but the difference of rice selling price per kilogram makes delay selling actors obtain more profit than those non-delays selling. Agribusiness development was also conducted by farming Business Corporation in which the farmers (i.e. farmers group MutiaraTani) in Selodakon Village runs it. As a start, pilot project with 10 hectare rice field was applied with irrigation technique starting from breeding to postharvest.

\section{REFERENCES}

1. Gaynor, P.E., and R.C. Kirk Patrick.(1994). Tome Series Modeling and Forecasting in Business and Economics. New York, Mc Graw hill.

2. Haley, Stephen.2013. World Raw Sugar Prices The Influence of Brazilian Costs of Production and World Surplus/ Deficit Measures. United States Department of Agriculture

3. Laws of the republic Indonesia. 2005. Undang-undang Republik Indonesia Nomor 9 Tahun 2006 tentang Sistem Resi Gudang. Jakarta.

4. Matsumura, Kanichiro.(2010). Demand and Supply Structure for Food in Asia. Sustainability 2011, 3, 363-395; doi: 10.3390/su3020363.

5. Maulidah, Silvana. 2012. Agribusiness System. Faculty of Agriculture. Malang: Brawijaya University. 
6. McConnell, Michael; Erik Dohlman; Stephen Haley. (2010). World Sugar Price Volatility Intensified by Market and Policy Factors.

7. McCormick, A. J. Watt, D. A. and Cramer, M. D.(2009). Supply and demand: sink regulation of sugar accumulation in sugarcane. Journal of Experimental Botany, Vol. 60, No. 2, pp. 357-364.

8. Pertani. 2012. Background of Warehouse Receipt System. Diakses pada https://pertaniupgjatim.wordpress.com/2012/07/12/latar-belakang-sistem-resi-gudang/

9. Riana, Dina. 2010. Use of Warehouse Receipt System. Faculty of Law. Jakarta: University of Indonesia.

10. Rumánková, Lenka and Smutka, Luboš. (2013). Global Sugar Market - The Analysis Of Factors Influencing Supply and Demand. Volume LXI. No. 2, pp. 463-471.

11. Sa'diyah, C. (2014). Factors that influence of economic performance for crystal sugar in Indonesia. (Thesis). Faculty of Agriculture. University of Brawijaya. Malang.

12. Sinaga, N. (2006). Model Econometric Aplication. IPB Post Graduate. Bogor.

13. Susila, Wayan.R and Bonar M. Sinaga. (2005). Analysis of Sugar Industry Policy in Indonesia. Jurnal Agro - Ekonomi Volume 23 No. 1, page 30-53.

14. Xue Xu and Hailong Xia.(2014). Analysis and Outlook of China's Sugar Industry Development. Proceedings of Selected Articles of 2013 World Agricultural Outlook.

15. Andrianto, M. S. 2016. Strategi Kesiapan UMKM Bogor dalam Menghadapi Persaingan Global. MANAJEMEN IKM: Jurnal Manajemen Pengembangan Industri Kecil Menengah, 11(2), 97-102.

16. Ariani, A., \& Utomo, M. N. 2017. Kajian strategi pengembangan Usaha Mikro Kecil and Menengah (UMKM) di Kota Tarakan. Jurnal Organisasi and Manajemen, 13(2), 99-118.

17. Badan Pusat Statistik Jawa Timura. 2018. Potensi Usaha Mikro Kecil. Diambil dari https://jatim.bps.go.id pada tanggal 7 April 2019.

18. Badan Pusat Statistik Jawa Timurb. 2018. Jumlah Penduduk and Laju Pertumbuhan Penduduk Menurut Kabupaten/Kota di Provinsi Jawa Timur, 2010, 2016 and 2017. Diambil dari https://jatim.bps.go.id pada tanggal 7 April 2019.

19. Hermann, M., Pentek, T., \& Otto, B. 2016. Design Principles for Industrie 4.0 Scenarios. Disampaikan pada Seminar 49th Hawaiian International Conference on Systems Science.

20. Irianto, D. 2017. Industry 4.0; the Challenges of Tomorrow. Disampaikan pada Seminar Nasional Teknik Industri, Batu-Malang.

21. Tjandrawinata, R.R. 2016. Industri 4.0: Revolusi industri abad ini and pengaruhnya pada bidang kesehatan and bioteknologi. Jurnal Medicinus, Vol 29, Nomor 1, Edisi April. 